\title{
Case Studies: Female and Child Survivors of a Bomb-Blast in Pakistan
}

\section{Anita Aijaz* and Uzma Ambreen}

FCPS Psych, Dow University of Health Sciences, Karachi, Sindh Pakistan

From prehistoric warfare to the present-day global war on terrorism, human beings have managed to survive bloodshed through their resilience. However, over time, awareness about psychological trauma in response to natural and man-made disasters, and the subsequent need for psychological interventions, is increasing. "Women and children exposed to such trauma, exhibit more severe adverse responses than men. In these groups, the incidence of psychopathology, including distress symptoms, high-risk behaviors, and various psychiatric disorders is high after disasters" [1]. Moreover, "the severity of exposure to trauma is directly related to the incidence of posttraumatic stress disorder (PTSD), depression, separation anxiety, and generalized anxiety" [1]. Women are more "susceptible to developing and reporting posttraumatic stress disorder symptoms" $[2,3]$. Similarly women are "likely to perceive high fear of terrorism" [2]. "The lifetime prevalence of probable PTSD was significantly higher for women" [1]. This highlights the special needs of these vulnerable groups and need for development of specialized services for women and children.

On March $3^{\text {rd }}$, 2013 two, huge bomb-blasts, occurring in quick succession, spread terror in Abbas Town, a congested, middle-class neighborhood in Karachi, Pakistan, leaving 47 dead and 135 injured. The area is inhabited by a mix of Shi' ite and Sunni muslim sects, in an approximately 30:70 ratio, but it was widely believed that the blasts were meant to target the Shi'ite community.

Representatives from two organizations, the Forum for Secular Pakistan and Pakistan Association for Mental Health (PAMH) visited Abbas Town for need assessment, five days after the incident. On March $13^{\text {th }}$ and $20^{\text {th }}$, psychological counseling services were provided by a team of psychiatrists and psychologists to several women and children affected by the blast. Both authors were part of this team [4-6].

Anita Aijaz conducted 2 group sessions with children and women survivors separately to explore their psychological trauma being from a vulnerable group hypothesis was that they were deeply traumatized with specialized need for psychological services. Following are from a series of interviews provided by the corresponding author.

Mrs. N.Z., a 52-year Shi'ite woman, who lives in Abbas Town and also runs a private, charitable school in the area. She was asked about her initial reaction to the blast: "I was at home when I suddenly heard a loud noise. I looked up to see where the noise was coming from. I felt as if the entire roof was coming down. Within seconds, there was an even louder noise and the lights all around me went out. I realized then that it was a bomb blast. I ran out of my home, and I saw flames rising towards the sky. It was a night of death.”

Mrs. N.Z. described it as an unforgettable event: "Whoever witnessed that scene will never be able to forget it. How can anyone forget that scene? There were flames everywhere. Children came out of their houses, screaming. People were running for their lives. Pieces of shattered glass were falling on my house. Smoke was everywhere, filling the apartments and houses. People in upper floor apartments were burning and were unable to find their way down because the stairs had been destroyed. We were standing there, helplessly watching them burning."
"The bomb probably had chemicals, so the people whom the fire had spared, were reduced to pieces by these chemicals. People's bodies were blackened and broken into pieces, scattered all around. Bodies and body-parts were dropping from above. I told children and women to stop screaming, call the ambulance, turn off light-switches and gasvalves, and then I went back to my house to check on my grandchildren. Then, I gathered the women in the neighborhood and told them to pray with me, since there wasn't anything else we could do at that time".

"We live in a Muslim country. And this is a black mark on Islam's name."

In another interview, Ms.W., a 28 year old married woman, while crying and sobbing, told me, "I was at home and my husband had just returned from the office, when the blast occurred, we could not hear anything. "I immediately recognized that it is bomb blast as I had already experienced it once. I saw the body of a child, and I could not get that picture out of my mind. I couldn't sleep. I was afraid, and extremely angry. I was not hurt, but look at my condition, I am still scared. If my life is so disturbed, I can't imagine what it must be like for those who were injured or whose relatives were injured or have died. If a blast of this magnitude had occurred elsewhere in the world, that nation's people would have stood together. Here, up until now, many people's bodies have not been found. If a body-part, like a hand, is found, people keep hoping that the person might still be found alive....I could not imagine this would happen...I've been experiencing restlessness, tension, and palpitations since the blast. I can't sleep, and when I do, I dream about the blast."

A 10-year old girl, C, told us, "I have been feeling breathless since the blast. Whenever there is a power failure, I have difficulty breathing".

An 8-year old girl, M, said “My father died in the blast. I don't want to live here any longer".

B, an 11-year old boy, who was at home when the blast occurred, was crying when he told us, "I have been feeling really anxious since the blast. I cannot sleep".

Ms. Y, while reciting prayers, told us," I saw a (severed) hand; I want to leave this area. There is no safety for us in Pakistan any longer. Where should we go? What if something like this happens to me tomorrow?"

Mrs. N.Z., herself from the Shi'ite community, shared her experience of Shi'ite and Sunni Muslims living together in Abbas town. "We have a good system for maintaining sectarian harmony in

*Corresponding author: Anita Aijaz, FCPS Psych, Dow University of Health Sciences, Karachi, Sindh Pakistan, E-mail: anita.aijaz@gmail.com

Received January 30, 2014; Accepted February 24, 2014; Published February 26, 2014

Citation: Aijaz A, Ambreen U (2014) Case Studies: Female and Child Survivors of a Bomb-Blast in Pakistan. J Trauma Treat S4: 011. doi:10.4172/2167-1222.S4-011

Copyright: (c) 2014 Aijaz A, et al. This is an open-access article distributed under the terms of the Creative Commons Attribution License, which permits unrestricted use, distribution, and reproduction in any medium, provided the original author and source are credited. 
our neighborhood. Shi'ites's willingly rent out portions of their houses to non-Shi'ite Muslims, as well as to families from different ethnic backgrounds, without any concerns that they might be harmed by them. Here, if one house belongs to a Shi'ite family, then 3 houses belong to Sunni families. Yet, this area was targeted as a Shi'ite area. After the blast, people from both sects co-operated in searching for the survivors as well as the bodies of the victims, without any discrimination. I swear that when my husband came into the house crying, my first question was, 'How is Brother A.Q.'s Shop?' He belonged to the Sunni sect, and he started his shop here when he hadn't even grown any facial hair. And now, he is married and has children. Just opposite his shop is a Shia's shop, but most Shi'ites prefer to go to A.Q.'s shop because he is pleasant and cordial to everyone. Today, everyone is praying for him because he was injured in the blast. I have many Sunni children studying in my school. Even though the Shi'ite community appeared to be the target of the bomb-blast, many Sunni's have also died. I lay awake last night wondering what their fault was."

"Every single person who died was known to me by name. My own nephew was on his way home, and died in the blast. Psychological wounds are deeper than physical wounds. There is a teacher in my school, her brother died on his way back from the vegetable market. He had just started a new job, with a good salary, two months ago. His mother had struggled with financial problems all her life, and he used to tell her that now, her troubles would be over. When the blast happened, he shielded his mother. His mother went from one private hospital to another, with her injured son, in an ambulance, but they wouldn't treat him, since this was a "medico-legal case", and she was told to take him to a government hospital. He died in the ambulance without getting any treatment. She refused to get treatment for her own injuries, saying why would an old woman want to live, when her young son had died?"

"This child sitting here was sent to me for a job by his mother. $\mathrm{He}$ told me he wanted to study but his parents were unable to bear the expenses. I told him that he didn't have to work, and that he could study in my school for free. He was really crazy about studying, but since the blast, he has been refusing to study. He says, 'What's the point of studying, when we are just going to die? I have seen people dying, in the fire. Pieces of their bodies were falling from the buildings!' And he keeps crying. The day of our death is already written, and no one can avoid the grave, but giving so much mental tension to this poor person who have many children to feed and earn their livelihood on daily wages, is just not right. These people come to this city from far away towns and work hard for very little wages. A vegetable-vendor, who came here from a distant village, was living with his family in a rented house. All three of his daughters study in my school. And now, he's dead and his wife and three daughters have no source of income and no one to look after them. All of them need counseling”.

"We are not afraid of death. The Shi'ites are a peaceful community, and when they do raise their hand, it is (not to hurt anyone else but) to beat their own chest (in mourning). And when they pick up a fetter, it is to hit them (in mourning). They do not believe in hurting other people".

In the conclusion these case studies prove again that women and children are vulnerable groups in the face of terrorist attacks and need specialized psychological interventions.

\section{References}

1. Corrarino JE (2008) Disaster-related mental health needs of women and children. MCN Am J Matern Child Nurs 33: 242-248.

2. Murphy SA (2010) Women's and children's exposure to mass disaster and terrorist attacks. Issues Ment Health Nurs 31: 45-53.

3. Sciancalepore R, Motta RW (2004) Gender related correlates of posttraumatic stress symptoms in a World Trade Center tragedy sample. Int J Emerg Ment Health 6: 15-24.

4. Pulcino T, Galea S, Ahern J, Resnick H, Foley M, et al. (2003) Posttraumatic stress in women after the September 11 terrorist attacks in New York City. J Womens Health (Larchmt) 12: 809-820.

5. Shigemura J, Fullerton CS, Ursano RJ, Wang L, Querci-Daniore R, et al. (2010) Gender differences in the fear of terrorism among Japanese individuals in the Washington, D.C. area. Asian J Psychiatr 3: 117-120.

6. Stuber J, Resnick H, Galea S (2006) Gender disparities in posttraumatic stress disorder after mass trauma. Gend Med 3: 54-67.
This article was originally published in a special issue, Post Traumatic Stress Disorders handled by Editor(s). Dr. Agius M, University of Cambridge, UK 